\title{
Access to banks and external capital acquisition: perceived innovation obstacles
}

\author{
Mikaela Backman $^{1}$ (D) Tina Wallin ${ }^{1}$
}

Received: 10 October 2017 / Accepted: 16 March 2018 / Published online: 17 April 2018

(C) The Author(s) 2018

\begin{abstract}
We examine whether low access to banks is perceived as problematic when obtaining financial capital for innovation activities. Data on innovation obstacles from the Swedish Community Innovation Survey are combined with geo-coded data at the firm level, which allows us to proxy access to external capital by the Euclidian distance from each firm to its nearest bank and the supply within a radius of $5 \mathrm{~km}$. The results indicate that both a longer distance to the nearest bank and fewer banks in the vicinity are related to experiencing greater difficulties in obtaining external financial capital for innovations.
\end{abstract}

JEL Classification D53 - G21 - G23 - L25 - O31

\section{Introduction}

In this paper, we analyse whether low access to banks increases the difficulty of acquiring external financial capital among firms that wish to innovate. In the EU, banks are by far the most common providers of loans to firms (European Commission 2011). Overall, $87 \%$ of the firms that were granted loans during 2009-2011 obtained them from a bank. Only $4 \%$ obtained loans from private individuals, such as family members or friends, and $8 \%$ obtained loans from other sources, such as microfinance institutions or government-related sources. The same pattern can be observed in Sweden, which

\footnotetext{
$凶$ Tina Wallin

tina.wallin@ju.se

Mikaela Backman

mikaela.backman@ju.se

1 Centre for Entrepreneurship and Spatial Economics (CEnSE), Jönköping International Business School, Jönköping, Sweden
} 
has a financial system that is bank-oriented and founded on relationships between banks and their customers (Avdeitchikova 2008; Sjögren and Zackrisson 2005). Most Swedish firms use bank loans; small- and medium-sized enterprises are particularly reliant on banks for their external financial funding needs (Berggren et al. 2001).

Although banks are the main providers of financial capital to firms, there has been a drastic change in the organisation of the local financial infrastructure. Between 1990 and 2010, approximately half of Sweden's local bank branches closed, a development that was particularly prevalent in rural areas. This change was problematic, as studies find that access to financial capital is important for both new firm formation (Backman 2015) and firm-level innovations (Hall et al. 2016; O'Sullivan 2005). In addition, studies find that it is the local financial infrastructure that is important for many firms (Backman 2015; Cole 1998; Cole et al. 2004; Ferri and Messori 2000; Fritsch and Schilder 2008; Lutz et al. 2013; Pollard 2003).

Using this development as a starting point, our purpose is to analyse how access to financial capital, proxied by the Euclidian distance to bank branches and the number of bank branches in the surrounding areas, is related to firms' perceived difficulties in obtaining external financial capital for their innovation processes. By doing so, we extend previous findings that financial obstacles impede firms' innovative capabilities (Alessandrini et al. 2010; Blanchard et al. 2013; Canepa and Stoneman 2008; Lee and Brown 2017). Our research contributes to the field of the literature in several aspects. First of all, the main contribution of this study is the ability to relate the exact distance between the firm and the bank branch, i.e. we analyse the operational distance between bank branch and the borrower. We test how the Euclidean distance between a bank branch and the firm influences the firm's ability to acquire external capital for innovation. Previous studies have used a region's overall supply of bank branches. It further allows us to move away from administrative borders and can measure urbanity and rurality as a continuous measure rather than separating administrative borders into different regional taxonomies. Second, despite a growing field, the geography of debt financing has been less extensively analysed compared to, for example, venture capital. Lastly, it is the first study on the importance of geographical distance and financing in innovative firms in a Swedish context. Doing research on Sweden complements the previous studies that have analysed the situation in, for example, the UK and in Italy. Sweden is a bank-oriented country where distance and peripherality make a large difference for firms and their daily practices.

Focusing on innovations also has several advantages. By definition, innovations are accompanied by a high degree of uncertainty, and firms often require external capital to finance their innovative activities (Canepa and Stoneman 2008; Hall et al. 2016). Thus, banks have high monitoring costs related to these kinds of projects. By focusing on innovations, we also reduce the heterogeneity associated with the numerous purposes for which a firm can use borrowed funds. We use the demand perspective in this paper whereby we analyse a firm's perceived difficulties in obtaining capital. We acknowledge the importance of the supply side, but because of data limitations, we are unable to further investigate this aspect of the issue.

To answer our research question, we combined the Community Innovation Survey (CIS) wave from 2010 with detailed geo-coded data on firms at the coordinate level. From the CIS, in which firms are requested to rank (in terms of magnitude) the prob- 
lems they have encountered when acquiring external financial capital, it is possible to observe perceived obstacles to innovation. Our hypothesis is that lower access to banks is associated with larger perceived obstacles to obtaining capital for innovation. This hypothesis is examined using a logit model in which we include distance to the nearest bank branch, the total number of bank branches in the vicinity, and firmand region-level controls. The results show that longer distance is associated with a higher probability of a firm experiencing external capital problems. In addition, the local supply of bank branches appears to be important, as a larger number of local bank branches are associated with a lower probability of experiencing external capital problems.

The implications of our results are that low access to banks renders firms less innovative as a result of perceived financial constraints. Technically, such constraints arise when there is a difference between the rate of return required by the owner investing internal funds and the rate of return required by external actors in the investment activity. Thus, a firm is financially constrained if it cannot obtain external capital at the market price (Hall 2002; Hubbard 1998). The consequence of firms encountering external financial constraints while lacking internal funds is less innovation activity than is optimal and thus market failure. Regulations that target the financial sector (e.g. Basel III and MiFID), which reduce banks' ability to provide finance, also lead to a tighter credit supply. Combined with the ongoing trend towards the closure of bank branches, especially in rural areas, we may observe severe problems in the long run, with firms performing less than optimally because of their diminished ability to conduct innovative activities.

This paper is organised as follows. Section 2 presents an overview of why access to financial intermediaries matters to firms and presents a brief background description of the Swedish financial sector. Section 3 presents the data, variables and method employed. Section 4 presents the results of the empirical estimations, and Sect. 5 concludes this paper.

\section{Why is geographical proximity to financial intermediaries important?}

Schumpeter's (1911) argument that services provided by financial intermediaries are essential to economic growth has been confirmed in numerous studies (Becchetti and Trovato 2002; Beck et al. 2000; Goldsmith 1969; King and Levine 1993). In this paper, we argue not only for financial intermediaries' competitive advantage in handling information but also for their importance at the local level.

An economic actor seeking access to financial capital must be able to provide the investor with sufficient information about the business idea and information about the borrower, such as personal characteristics and previous activities. This information can be either "hard", i.e. verifiable information, or "soft", i.e. "information that cannot be directly verified by anyone other than the agent who produces it" (Stein 2002, p. 1892). Soft information is often difficult to communicate to others or record in a document (Udell 2008). Therefore, it is costly for the financial intermediary to acquire, as it requires personal meetings and trust, which are often developed through a long-term relationship, i.e. relationship lending (Boot 2000; Elsas and Krahnen 1998; Gereffi 
et al. 2005; Storper and Venables 2004). As such, soft information has a clear spatial component and is easier and cheaper to convey over short distances. Thus, regional and local financial institutions are particularly important for firms that are more dependent on soft information and personal relationships (Berger et al. 1999; Collender and Shaffer 2003; Kwast 1999). Agarwal and Hauswald (2010) focus on the physical distance between small firms, which are generally informationally opaque, and their lending counterparts, banks in the USA. They find that the quality of soft information is a negative function of the distance between the borrower and lender. Thus, there is a strong local pattern when handling soft information where banks are able to have a local informational advantage.

Despite improved communication and technology such as Internet banking, which allows for longer distances between lenders and borrowers, it has been found that banks continue to depend on personal relationships (Boot and Marinč 2008; Petersen and Rajan 2002). A close relationship and closer geographical proximity between the bank and the borrower also facilitate monitoring and screening activities (Boot 2000). Another reason for the importance of proximity between the lender and borrower is that proximity enables financial intermediaries to access knowledge about the local market that can be incorporated when deciding whether to make a loan (Hayek 1945; Pollard 2003). Several studies also find that financial intermediaries prefer to invest within a close geographical context (Cole 1998; Cole et al. 2004; Ferri and Messori 2000; Fritsch and Schilder 2008; Lutz et al. 2013).

Having close geographical proximity to many financial intermediaries signals the level of competition. There are ambiguous findings about whether competition within the financial sector is beneficial for the remainder of the economy. Some argue that increased market power reduces the equilibrium amount of credit granted and increases interest rates for borrowers (Beck et al. 2004; Berger et al. 1999; Degryse and Ongena 2005; Dinc 2000; Gilbert 1984; Sharpe 1990). Others argue that some level of market power is needed for a bank to establish a fruitful lending relationship (Petersen and Rajan 1995). In the case of a long-term relationship, the bank can use the option of smoothing interest rates over time to provide an initially subsidised rate, for which the bank can be compensated later in the relationship (Boot and Marinč 2008). In the case of harsh competition, the scenario is that the bank and the customer are unable to establish this type of long-term relationship because the customer is more prone to shift banks later.

The previous article analysing the relationship between the distance to financial intermediaries and firm performance finds that distance between firms and lenders is of importance. Studies normally focus on either being close geographically, i.e. operational distance, or having proximity in an organisational sense, i.e. functional distance which measure the distance between the bank branch and headquarter. Flögel (2017) uses the concept of functional distance to assess how it relates to the access of soft information. He finds that shorter functional distance positively relates to the acquisition of soft information. Using a network analysis applied to the geography of the Italian banking industry and the relationships among the key actors to captures the functional distance. Papi et al. (2015) find that the urban-rural split in the financial and banking sector has been even more consolidated over time. 
Degryse et al. (2015) analyse how the functional distance impact small- and medium-sized firms in the UK. The authors relate the functional distance between firms and lenders to the regional variation in financial supply of bank credit. They find that an increase in the functional distance lowers the credit supply during the financial crises. Zhao and Jones-Evans (2017) conduct a similar study where they analyse the relationship between functional and operational distance for UK firms during the financial crises. They find evidence that the functional distance relates to a firm's ability to access finance while the operational distance shows an ambiguous effect. Studies show that both proximities matter for firms in their quest in accessing finance. Thus, there is a spatial component to both proximities. In this paper, we solely focus on the operational distance.

\subsection{The case of innovation}

The importance of financial capital as an input in the innovation process has been verified by several prominent scholars (Lundvall 1992; Nelson and Winter 1982; Schumpeter 1934, 1939). The importance of financial capital for innovations stems from the uncertain nature of the innovation process (Hall 2002). Firms spend time and effort developing an idea either through formal R\&D activities or through regular operations. To cover the costs of these risky investments, firms must be able to appropriate monopoly rents in cases in which an innovation succeeds (Aghion and Howitt 1992; Schumpeter 1934). This statement implies that with non-commercialised innovations, the firm does not know whether it will be successful, and potential profit streams have not yet been realised. Hence, other financial resources are needed to fund the actual process. If the innovation process was predictable and investors could correctly estimate the return on their investments, it would not be difficult to attract investors and acquire financial capital for profitable innovations. However, because the innovation process exacerbates uncertainty, which creates information asymmetry, investors have difficulty identifying the actual risk and thus may choose not to become involved (Hall et al. 2016).

Canepa and Stoneman (2008) analyse the relationship between financial constraints and innovative activities using CIS data for British firms. They find that low access to finance is a factor that decreases the innovative probability of firms. Similar studies have been conducted based on CIS data in other countries, such as the Netherlands (Mohnen et al. 2008), France (Blanchard et al. 2013) and Italy (Alessandrini et al. 2010). They all support the finding that financial obstacles hamper firms' innovation activities. Lööf and Nabavi (2016) analyse how financing constraints relate to patent applications and new export products for Swedish firms. They conclude that financial constraints have a negative relationship with patent applications in high-tech firms, regardless of the business cycle. Focusing on innovative small- and medium-sized firms in the UK, Lee and Brown (2017) analyse how the regional supply and demand of financial funds through banks varies in the UK. They find regional differences where innovative firm in rural locations have a higher demand for financial funds but that these firms are more discouraged from applying and more often rejected, holding credit score constant. The study is, however, not able to capture the functional or 
operational distance as they use a regional taxonomy with two categories to define the geographical aspect. Based on discussions and findings in previous studies, we formulate the following hypotheses:

Hypothesis 1 Low access to banks resulting from large geographical distances between firms and banks increases firms' difficulties in attracting external capital for innovation activities.

Hypothesis 2 Low access to banks resulting from small numbers of bank branches in the near vicinity of firms increases firms' difficulties in attracting external capital for innovation activities.

\subsection{The Swedish financial sector}

The Swedish financial system has long been characterised by a strong bank orientation that is heavily based on relationships (Avdeitchikova 2008; Sjögren and Zackrisson 2005) and rather oligopolistic. The four Swedish-owned commercial bank corporations-Swedbank, SEB, Nordea and Handelsbanken-account for approximately $70 \%$ of the market, depending (to some degree) on the types of services offered (Bankföreningen 2010). However, Stenfors (2014) claims that the rapid deregulation of the financial sector in the 1980s and 1990s moved Sweden to a more central position in the typical dichotomy of a bank-centred versus a market-centred system. Additionally, the tax system was reformed during this period, and debt has become less favoured, also suggesting a move towards a more market-oriented system (Månsson and Landström 2006). Despite these structural changes, a recent report by Sweden's largest trade association highlights that banks remain firms' most important source of external capital (Företagarna 2015).

Venture capital is often seen as an alternative source of capital but represents a small share of the Swedish market (Företagarna 2015; Reynolds et al. 2003; Söderblom 2012; Söderblom and Samuelsson 2014). Venture capital also has a small geographical reach, as most firms are concentrated in the two largest metropolitan regions: Stockholm and Gothenburg (Berggren and Silver 2010). Other actors in the financial sector include informal venture capitalists or business angels, who account for a small share of external capital provided (Avdeitchikova 2008). In addition to private actors in the Swedish financial market, there is the state-owned organisation, Almi, which is the largest supplier of public debt (Söderblom 2012). Almi is responsible for the government's incubator programme, providing loans, venture capital and advisory functions to both start-ups and established firms from approximately 40 locations across Sweden (Almi 2016).

The development of the banking sector in Sweden from 1993 to 2010 is illustrated in Fig. 1. Because there are large differences in development in different regions, four regions are displayed as separate lines. The regions are based on the regional taxonomy described in Westlund (2011):

1. Metropolitan municipalities: municipalities in the functional regions of Stockholm, Gothenburg and Malmö. 


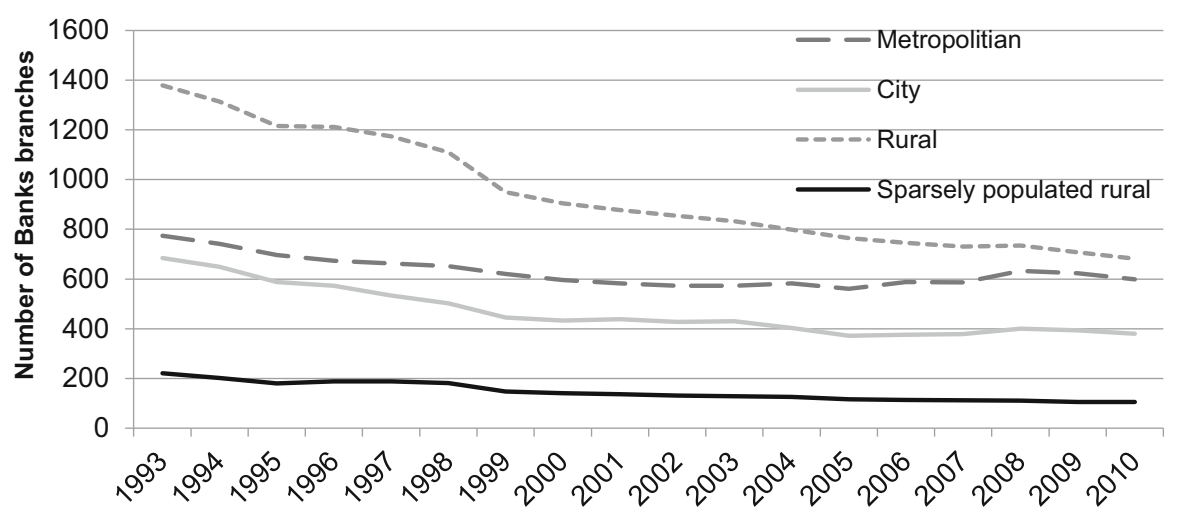

Fig. 1 Number of bank branches in different regional categories, 1993-2010

2. Urban municipalities: regional centres outside the metropolitan areas and their "suburb municipalities".

3. Rural municipalities: municipalities not part of (1) or (2), with a population density above five people per $\mathrm{km}^{2}$.

4. Sparsely populated rural municipalities: population density below 5 people per $\mathrm{km}^{2}$.

As the figure shows, the total number of bank branches has declined over the examined period, and there are large differences among regional groups. The largest decline in the number of bank branches occurred in the sparsely populated rural municipalities, where approximately half of bank branches closed during this period. These are also regions in which there are few alternative financial sources. For metropolitan and city regions, the change in the number of bank branches has been less drastic, and the number of bank branches has even increased somewhat in later years. The patterns illustrated in Fig. 1 are based on the absolute number of bank branches. However, the same pattern emerges when weighting the number of bank branches by population in the corresponding regions. Thus, the tendency is not solely driven by the general urbanisation trend.

\section{Data, variables and method}

Several databases are combined to empirically address the research question: detailed information on the locations of bank branches, firms and the regions in which firms are located. All data used in this paper are collected by Statistics Sweden and are subject to restricted public access.

To identify obstacles to innovation, we use the 2010 wave of the CIS. The CIS is based on a harmonised survey compiled by Eurostat and conducted in Sweden by Statistics Sweden at a 2-year frequency. Hence, the 2010 wave of CIS captures firm reports of innovative activities from 2008 to 2010. An advantage of this survey is its broad definition of innovation. The product and/or process is not required to be new to the market to be classified as an innovation; it is sufficient that it is new to the 
firm. Another advantage is that the survey mostly contains small- and medium-sized firms. While the survey was sent to the entire population of large enterprises (250 employees), small- and medium-sized firms (with 10-249 employees) are randomly drawn from a stratified sample (based on size and sector). Hotels and restaurants, as well as agriculture and forestry, construction and the public sector, are excluded. The choice of excluded sectors is made by Statistics Sweden. Only micro-firms are missing from the sample.

In contrast to previous waves, the 2010 wave of CIS includes a question about obstacles to innovation. This wave includes 4552 firms. However, because the localisation of the firms is important for our hypotheses, it is problematic to include multi-establishment firms, i.e. firms that have more than one establishment in different locations (approximately one-third of the firms). These firms are therefore excluded unless we can observe that a firm consists of one large establishment at which a clear majority (more than 80\%) of all employees are located and that additional establishments have only 1-2 employees each, presumably in sales offices. In this way, approximately 130 firms were retained in the dataset together with the approximately 3200 single-establishment firms. To access detailed information about the firms, we use employee-employer matched register data from Statistics Sweden. Data for the banks are collected from Statistics Sweden and from Almi for public debt institutions. To obtain a proxy for the exact location of firms and bank branches, their coordinates were used. The data are structured as a grid in which all firms localised in the same square $(250 \mathrm{~m} \times 250 \mathrm{~m}$ in urban areas and $1000 \mathrm{~m} \times 1000 \mathrm{~m}$ in rural areas) are assigned the coordinates of the lower left corner. The fine grid allows us to precisely measure the geographical distances between firms and their nearest bank branches without being limited to administrative borders.

\subsection{Method}

The dependent variable consists of answers to a survey question whose categories have a natural order for a total of four categories. This type of ordinal information can be used in estimations via an ordered logit model (Cameron and Trivedi 2010). However, one assumption of this model is proportionality between thresholds. By performing a Brant test after estimating the regressions, we concluded that the proportionality assumption could not be confirmed (Brant 1990). In addition, a low percentage of responses in some categories made the tests unstable. To solve both problems, we transformed the dependent variable into a binary variable, where 0 indicates no problem and 1 indicates a problem without specifying the degree. Another advantage is that we are less dependent upon the respondents' subjective valuations of the scale of problems experienced. Thus, $y$ takes a value of 0 or 1, as displayed in Eq. (1).

$$
y=\left\{\begin{array}{l}
1 \text { if } y^{*}>0 \\
0 \text { if } y^{*} \leq 0
\end{array}\right.
$$


With this binary version of the variable, we estimate a logistic regression model in which the probability of $y$ being equal to one is displayed in Eq. (2).

$$
\operatorname{Pr}(y=1)=\operatorname{Pr}\left(\boldsymbol{x}^{\prime} \beta+u>0\right)=\operatorname{Pr}\left(-u<\boldsymbol{x}^{\prime} \beta\right)=F\left(\boldsymbol{x}^{\prime} \beta\right)
$$

$F$ is the cumulative distribution function of the error term, which in a logit model is logistically distributed (Cameron and Trivedi 2010; Greene 2008). The regression parameters are estimated by maximising the log likelihood function associated with the probability function. Hence, a positive regression parameter means that the variable in question increases the probability of the outcome, $y$, being one. In our case, the estimated model is presented in Eq. (3),

$$
\text { Perceived external capital obstacles }{ }_{i}=\alpha+\boldsymbol{\gamma}_{i}^{\prime} \boldsymbol{\beta}+\boldsymbol{z}_{\boldsymbol{m}}^{\prime} \boldsymbol{\delta}+u_{i}
$$

where the outcome variable, perceived external capital obstacles, is estimated as a function of a vector of firm-specific variables $\left(\boldsymbol{\gamma}_{\boldsymbol{i}}\right)$, including distance to various financial institutions and region-specific variables $\left(z_{m}\right)$, and $u_{i}$ is the error term. $\boldsymbol{\beta}$ and $\boldsymbol{\delta}$ are the parameters to be estimated. One problem with survey data such as the CIS is that firms have different probabilities of being selected for participation in their strata. If uncorrected, this difference could bias the estimates (Pfeffermann 1993). To alleviate this problem, we incorporate sample weights, provided by Statistics Sweden, in all regressions.

One additional issue is that firms may have experienced bank relocations during the period covered by the survey, implying that we do not know whether a given response relates to distance in 2007 or to changes that occurred in subsequent years. To address this issue, our main model only includes firms that did not experience changes in distance to the nearest bank from 2008 to 2010 . As a result, approximately 350 firms were excluded.

\subsection{Variables}

\subsubsection{Dependent variable}

Perceived external capital obstacles To test the hypotheses, we use a question from the CIS about obstacles to innovation. One obstacle included was "lack of financial capital from sources external to the firm" (Statistics Sweden 2012, p. 114). Specifically, the question asks firms to indicate, on a scale of $0-3$, how difficult it was to attract external financial capital during the 2008-2010 period, where 0 indicates that there were no difficulties at all and 3 indicates that there were serious difficulties. However, because of the methodological issues described in Sect. 3.1, we collapsed this variable into a binary measure, where 1 indicates that the firm did experience problems and 0 indicates that it did not. 


\subsubsection{Access to financial intermediaries}

Distance to the nearest bank branch The banks are identified by the NACE rev. 2 codes, and the Euclidean distance is calculated between the coordinates of each grid of the bank branch and those of the grid of each firm in the CIS data. The minimum distance in kilometres is then used for each firm. This variable is included to test Hypothesis 1.

Bank branches within a radius of $5 \mathrm{~km}$ To test Hypothesis 2, a measure of the local supply of financial capital is included by calculating the number of bank branches within a radius of $5 \mathrm{~km}$ of each grid of a firm.

\subsubsection{Control variables}

Distance to the nearest Almi office To control the access to other types of external capital, the geographical distance to the closest Almi office was used. Addresses were obtained based on information on Almi's webpage and its previous yearly reports. The coordinates were then manually obtained and used to calculate the Euclidean distance to Almi from each firm in the dataset. The minimum distance in kilometres was then used for each firm.

What banks and other financial intermediaries are attempting to establish, either with soft information or with hard information from financial statements, is whether a firm is likely to be able to repay its loan. Any financial (hard) information available should facilitate the decision and is relevant to include in our model (Berger and Udell 2006; Uchida 2011). Hence, we include two variables - a flow variable and a stock variable - that capture financial information about a firm.

Operating margin This variable is equivalent to EBIT (earnings before interest and taxes) divided by turnover (both measured in millions of SEK), which makes the measure less dependent on size. Hence, a firm with a negative operating margin is running at a loss, and a firm with a positive value could use the surplus to support innovative activities. It is important to note that by definition, EBIT is earnings before the firm has added potential interest income.

Total capital per employee This variable consists of tangible capital, such as machinery, and intangible capital, such as patents and trademarks, measured in millions of SEK. This variable indicates whether a firm has any collateral to use for a loan (Berger and Udell 2006; Mina et al. 2013; Uchida 2011). To normalise this variable for the size of the firm, we divide the value of capital by the number of employees.

Number of employees This variable is included as a proxy for firm size. Larger firms have the ability to produce a larger variety of products, as they tend to have more resources, and they can also take greater advantage of economies of scale and scope (Cohen and Klepper 1996; Scherer 1965). The size of the firm is a factor that financial intermediaries include when attempting to determine whether a project proposed by a firm is likely to succeed. Larger firms are generally less capital constrained and 
associated with less uncertainty. The size of the firm can also affect the type of investor that is interested in investing.

Age The age of the firm can be considered a proxy for the stock of experience existing in a firm. The firm may have tested and attempted many things over the years and thus have a sense of what works and what does not. The firm also has experience and knowledge of both its industry and the region in which it operates (Balasubramanian and Lee 2008; Majocchi et al. 2005). In addition, a higher age means that a longer history of financial statements is available to the financial intermediary (Gereffi et al. 2005; Storper and Venables 2004).

Corporate group This is a binary variable, where 1 indicates that the firm is part of a corporate group and 0 indicates that it is not. It is included to control the ownership structure of the firm. Because public firms are excluded in the CIS sampling process, two possible categories remain: private Swedish firms and firms that are part of a corporate group. The ownership structure could be an indicator of innovation success, as several studies have found that multinational firms are more innovative than others, possibly because of intra-organisational knowledge spillovers (Cook et al. 2013; Dachs et al. 2008; Johansson and Lööf 2008). From a financial perspective, if financial capital is needed, being owned by another firm could indicate potential support from other parts of the organisation.

Exporting status This is a binary variable, where 1 indicates that the firm engaged in exporting activity in 2007 and 0 indicates that it did not. Because exporting firms often are more productive than others (Alessandria and Choi 2007; Baldwin and Krugman 1989; Bernard and Jensen 2004; Bernard and Wagner 2001; Das et al. 2007), exporting status could serve as an indicator of external knowledge flows and foreign contacts, both of which could be relevant to determining the success of a loan grant. However, it could also be an indicator of less transparency in the firm and greater risk (Mina et al. 2013).

Internal human capital This variable is measured as the share of employees with at least 3 years of university education. Human capital is included in the model to proxy for the important input of knowledge used in innovation processes (Thornhill 2006), assuming that individuals with higher education levels are equipped with useful skills.

Distance to nearest city centre Because many bank branches are located close to city centres, there is a risk that the variable distance to nearest bank branch at least partially captures a central location rather than the location in relation to bank branches. To address this problem, we included the coordinates of each municipality's main city centre and used that to calculate the Euclidean distance to them from each firm in the dataset. The minimum distance in kilometres is then used for each firm.

In addition to firm variables, we include region-specific variables. For region in this case, we refer to municipalities, of which there are 290 in Sweden. 
Establishments per bank Because financial intermediaries do not have unlimited resources, more establishments competing for those resources should, all else being equal, decrease each firm's likelihood of receiving a loan or an investment. We measure this variable as the number of establishments in the municipality divided by the number of bank branches in that municipality.

Wage sum per inhabitant This variable proxies two aspects of the regional economy. The wage sums are highly correlated with the real estate value. As these are used as collateral in the majority of all bank loans in Sweden, both to private and business customers, a higher wage sum signals a higher collateral value, thus facilitating access to external capital. Approximately $10 \%$ of all bank branches in Sweden are local savings banks that operate on a much more local scale than regular bank chains, for these banks the local resources are especially relevant as their capacities to grant loans depend on the money lent to them, according to legislated directives regarding capital requirements.

In addition to including characteristics as independent variables, we split the dataset by type of region and type of industry. The regional categories used are (1) urban municipalities and (2) rural municipalities. These regions build upon the categorisation of Westlund (2011), explained in Sect. 2.2, except that we combine the two urban categories and the two rural categories. Financial institutions such as banks are very concentrated in the central municipalities of the three largest cities: Stockholm, Gothenburg and Malmö. Of the 290 municipalities, these three are outliers, with almost $20 \%$ of all bank branches, and bias the results for the remainder of the urban municipalities. The three municipalities are therefore excluded from all estimations and descriptive statistics to make the study more relevant to urban municipalities throughout Sweden. As the probability of receiving loans and investments may differ between industries, because of potentially differing collateral levels, we control the industry by including dummies and running separate regressions for manufacturing and services. These two groups contain the majority of firms, making it infeasible to use the few remaining and heterogenous firms to form a miscellaneous group.

\subsection{Descriptive statistics}

Table 1 displays the distribution of the dependent variable. Approximately $40 \%$ of firms in urban areas and $45 \%$ of firms in rural areas reported that they experience problems acquiring external financial capital. Of the firms that reported having problems, the majority categorise these problems as small or medium, whereas almost one in five firms reporting problems categorise them as large.

To conform to the split in the dataset by type of region and to indicate that there are large differences motivating that division, the descriptive statistics for our independent variables in Table 2 are also presented according to region type. The average distance to the nearest bank branch is small in both types of region: $2.1 \mathrm{~km}$ in urban areas and $3.5 \mathrm{~km}$ in rural areas. Although this difference is small, it is statistically significant. This confirms that bank branches are available throughout the country. It can, however, be observed that there is greater variation in distance for firms in rural municipalities. 
Table 1 Distribution of the dependent variable

\begin{tabular}{|c|c|c|c|c|c|c|}
\hline \multirow{2}{*}{$\begin{array}{l}\text { External capital } \\
\text { problems }\end{array}$} & \multicolumn{2}{|l|}{ Urban } & \multicolumn{2}{|l|}{ Rural } & \multicolumn{2}{|l|}{ Total } \\
\hline & Count & $\%$ & Count & $\%$ & Count & $\%$ \\
\hline $\begin{array}{l}\text { Not a problem at } \\
\text { all (0) }\end{array}$ & 687 & 59.84 & 638 & 55.14 & 1325 & 57.48 \\
\hline It is a problem (1) & 461 & 40.16 & 519 & 44.86 & 980 & 42.52 \\
\hline Sum & 1148 & 100 & 1157 & 100 & 2305 & 100 \\
\hline Small problem & 220 & 47.72 & 254 & 48.94 & 474 & 48.37 \\
\hline Medium problem & 157 & 34.06 & 163 & 31.41 & 320 & 32.65 \\
\hline Large problem & 84 & 18.22 & 102 & 19.65 & 186 & 18.98 \\
\hline Sum & 461 & 100 & 519 & 100 & 980 & 100 \\
\hline
\end{tabular}

The category "urban" excludes the municipalities of Stockholm, Gothenburg and Malmö

In general, firms appear to be closer to bank branches than to Almi offices, which are as expected, as there are more bank branches than Almi offices. There is a clear difference in the number of banks within a vicinity (proxied by the number of bank branches within a radius of $5 \mathrm{~km}$ ) that firms in different regional categories can access. Firms in urban municipalities have local access to ten bank branches on average, whereas rural firms have access to only two. Thus, although distance to the nearest bank is similar across the two regional categories, the locally available supply differs, confirmed by a $t$ test of the means.

\section{Empirical results}

The estimations are presented in Table 3, where all results are displayed as odds ratios; thus, values below 1 indicate a negative relationship with the outcome variable, and values above 1 indicate a positive relationship. Importantly, $y=1$ indicates a perceived problem, while a 0 does not. Hence, odds ratios greater than 1 are positively related to firms experiencing problems, which would be perceived as negative for the firms. The dummy variables used to distinguish between manufacturing and service firms and between urban and rural firms in the first three columns validate a further separation of the sample, as they are significantly different from one.

\subsection{Access to banks}

The overall findings show that access to banks is related to perceived difficulties for firms in attracting external capital, confirming both Hypothesis 1 (larger geographical distance increases difficulties for firms in attracting external capital for innovation activities) and Hypothesis 2 (fewer bank branches in the near vicinity of the firm increases difficulties for firms in attracting external capital for innovation activities). 
Table 2 Descriptive statistics displayed separately for firms located in urban areas and rural areas

\begin{tabular}{|c|c|c|c|c|c|c|c|}
\hline \multirow[t]{2}{*}{ Variables } & \multirow[t]{2}{*}{ Description } & \multicolumn{3}{|c|}{ Urban regions } & \multicolumn{3}{|c|}{ Rural regions } \\
\hline & & Mean & Median & $\mathrm{SD}$ & Mean & Median & $\mathrm{SD}$ \\
\hline $\begin{array}{l}\text { Dist. to nearest } \\
\text { bank branch }^{\mathrm{a}}\end{array}$ & $\begin{array}{l}\text { The Euclidean } \\
\text { distance to the } \\
\text { nearest bank } \\
\text { branch in } \\
\text { kilometres }\end{array}$ & 2.127 & 1.458 & 2.523 & 3.448 & 1.458 & 5.124 \\
\hline $\begin{array}{r}\text { Bank branches } \\
\text { within } 5 \mathrm{~km}^{\mathrm{a}}\end{array}$ & $\begin{array}{l}\text { The number of } \\
\text { bank branches } \\
\text { located within a } \\
5 \text { kilometers } \\
\text { radius of the } \\
\text { firm }\end{array}$ & 10.36 & 6 & 16.29 & 2.308 & 2 & 1.733 \\
\hline $\begin{array}{l}\text { Dist. to nearest } \\
\text { Almi office }\end{array}$ & $\begin{array}{l}\text { The Euclidean } \\
\text { distance to the } \\
\text { nearest Almi } \\
\text { office in } \\
\text { kilometres }\end{array}$ & 10.39 & 5.846 & 10.52 & 43.99 & 39.48 & 31.30 \\
\hline Operating margin & $\begin{array}{l}\text { EBIT in thousands } \\
\text { of SEK divided } \\
\text { by turnover in } \\
\text { thousands of } \\
\text { SEK }\end{array}$ & -19.22 & 0.056 & 490.4 & 0.051 & 0.054 & 0.170 \\
\hline $\begin{array}{c}\text { Total assets per } \\
\text { employee }^{\mathrm{a}}\end{array}$ & $\begin{array}{l}\text { The value of all } \\
\text { assets in MSEK } \\
\text { divided by the } \\
\text { number of } \\
\text { employees }\end{array}$ & 0.418 & 0.123 & 2.707 & 1.530 & 0.237 & 34.81 \\
\hline Employees $^{\mathrm{a}}$ & $\begin{array}{l}\text { The number of } \\
\text { employees in the } \\
\text { firm }\end{array}$ & 54.43 & 21 & 123.2 & 63.07 & 27 & 115.3 \\
\hline$<5$ years old & $\begin{array}{l}\text { Age of the firm, } \\
\text { with less than } 5 \\
\text { years old as the } \\
\text { base }\end{array}$ & 0.116 & 0 & 0.320 & 0.063 & 0 & 0.243 \\
\hline 5-9 years old & Age of the firm & 0.137 & 0 & 0.344 & +0.103 & 0 & 0.304 \\
\hline $10-14$ years old & Age of the firm & 0.145 & 0 & 0.353 & 0.113 & 0 & 0.317 \\
\hline $\begin{array}{l}\text { At least } 15 \text { years } \\
\text { old }\end{array}$ & Age of the firm & 0.602 & 1 & 0.490 & 0.721 & 1 & 0.449 \\
\hline $\begin{array}{l}\text { Private Swedish } \\
\text { firm }\end{array}$ & $\begin{array}{l}\text { Ownership status } \\
\text { of the firm, with } \\
\text { private Swedish } \\
\text { firm as the base }\end{array}$ & 0.332 & 0 & 0.471 & 0.357 & 0 & 0.479 \\
\hline Corporate group & $\begin{array}{l}\text { Ownership status } \\
\text { of the firm, with } \\
\text { private Swedish } \\
\text { firm as the base }\end{array}$ & 0.668 & 1 & 0.471 & 0.643 & 1 & 0.479 \\
\hline Exporting status & $\begin{array}{l}1 \text { if the firm } \\
\text { exported in } 2007 \\
\text { and } 0 \text { otherwise }\end{array}$ & 0.660 & 1 & 0.489 & 0.730 & 1 & 0.444 \\
\hline
\end{tabular}


Table 2 continued

\begin{tabular}{|c|c|c|c|c|c|c|c|}
\hline \multirow[t]{2}{*}{ Variables } & \multirow[t]{2}{*}{ Description } & \multicolumn{3}{|c|}{ Urban regions } & \multicolumn{3}{|c|}{ Rural regions } \\
\hline & & Mean & Median & SD & Mean & Median & $\mathrm{SD}$ \\
\hline $\begin{array}{l}\text { Internal human } \\
\text { capital }\end{array}$ & $\begin{array}{l}\text { The percentage of } \\
\text { employees with } \\
\text { at least a } \\
\text { bachelor's } \\
\text { degree }\end{array}$ & 16.47 & 8.333 & 21.53 & 6.167 & 2.857 & 11.23 \\
\hline $\begin{array}{l}\text { Dist. to nearest } \\
\text { city centre }^{\mathrm{a}}\end{array}$ & $\begin{array}{l}\text { The Euclidean } \\
\text { distance to the } \\
\text { nearest city } \\
\text { centre in } \\
\text { kilometres }\end{array}$ & 3.921 & 2.400 & 4.606 & 6.894 & 2.328 & 8.934 \\
\hline $\begin{array}{l}\text { Manufacturing } \\
\text { firm }\end{array}$ & $\begin{array}{l}1 \text { if the firm } \\
\text { belongs to the } \\
\text { manufacturing } \\
\text { sector }\end{array}$ & 0.518 & 1 & 0.500 & 0.714 & 1 & 0.452 \\
\hline Service firm & $\begin{array}{l}1 \text { if the firm } \\
\text { belongs to the } \\
\text { service sector }\end{array}$ & 0.301 & 0 & 0.459 & 0.145 & 0 & 0.352 \\
\hline $\begin{array}{l}\text { Establishments } \\
\text { per bank }^{\mathrm{a}}\end{array}$ & $\begin{array}{l}\text { The number of } \\
\text { establishments } \\
\text { divided by the } \\
\text { number of bank } \\
\text { branches per } \\
\text { municipality }\end{array}$ & 365.7 & 354.6 & 103.8 & 239.6 & 223 & 90.75 \\
\hline $\begin{array}{l}\text { Wage sum per } \\
\text { inhabitant }^{\mathrm{a}}\end{array}$ & $\begin{array}{l}\text { The wage sum in } \\
\text { thousands SEK } \\
\text { per municipality } \\
\text { divided by the } \\
\text { population }\end{array}$ & 121.9 & 119.6 & 51.96 & 96.37 & 93.08 & 18.90 \\
\hline
\end{tabular}

The category "urban" excludes the municipalities of Stockholm, Gothenburg and Malmö

${ }^{\mathrm{a}}$ The natural logarithms of these variable are used in the estimations to reduce skewness

The overall findings support studies such as Berger et al. (1999), Collender and Shaffer (2003) and Lutz et al. (2013).

The odds ratios measuring the distance to the nearest bank are significant and above one, implying that increased distance is associated with greater perceived difficulty in attracting external capital related to innovation activities. The findings confirm the importance of geographical distance between the firm and the bank branch. Previous studies have found that the functional distance, i.e. the distance within the bank organisation between hierarchical levels and the innovative firm, is important in terms of general access to banks (Alessandrini et al. 2010). We add to this by arguing that the Euclidean distance is also important. Geographical proximity to a bank enables a firm to more easily transfer information, in most cases soft information, about its innovation projects, reducing the degree of information asymmetry between the firm and the bank. Such projects also tend to carry a high degree of uncertainty in terms of 
Table 3 Regression results for external capital problems displayed as odds ratios

\begin{tabular}{|c|c|c|c|c|c|c|c|}
\hline & \multirow[t]{2}{*}{ All regions } & \multicolumn{2}{|c|}{ Urban and metro regions } & \multicolumn{2}{|c|}{ Urban regions } & \multicolumn{2}{|c|}{ Rural regions } \\
\hline & & Manuf. & Services & Manuf. & Services & Manuf. & Services \\
\hline Dist. to nearest bank branch & $\begin{array}{l}1.170 * * * \\
(0.0580)\end{array}$ & $\begin{array}{l}1.243 \\
(0.165)\end{array}$ & $\begin{array}{l}1.821 * * * \\
(0.319)\end{array}$ & $\begin{array}{l}\mathbf{1 . 0 4 4} \\
(0.150)\end{array}$ & $\begin{array}{l}1.905 * * * \\
(0.456)\end{array}$ & $\begin{array}{l}\text { 1.154* } \\
(0.0982)\end{array}$ & $\begin{array}{l}\mathbf{1 . 7 1 8} * * * \\
(0.306)\end{array}$ \\
\hline Bank branches within 5 km & $\begin{array}{l}0.991 \\
(0.0417)\end{array}$ & $\begin{array}{l}0.658 * * * \\
(0.0599)\end{array}$ & $\begin{array}{l}1.214 * * \\
(0.105)\end{array}$ & $\begin{array}{l}\mathbf{0 . 5 2 5} * * * \\
(0.0586)\end{array}$ & $\begin{array}{l}\mathbf{0 . 8 0 9} * \\
(0.0905)\end{array}$ & $\begin{array}{l}\mathbf{0 . 7 2 4} * * * \\
(0.0829)\end{array}$ & $\begin{array}{l}1.129 \\
(0.287)\end{array}$ \\
\hline Dist. to nearest Almi office & $\begin{array}{l}0.868 * * * \\
(0.0200)\end{array}$ & $\begin{array}{l}0.735^{* * *} \\
(0.0453)\end{array}$ & $\begin{array}{l}0.875 * * * \\
(0.0420)\end{array}$ & $\begin{array}{l}0.710^{* * *} \\
(0.0530)\end{array}$ & $\begin{array}{l}0.925 \\
(0.0548)\end{array}$ & $\begin{array}{l}1.008 \\
(0.0525)\end{array}$ & $\begin{array}{l}0.989 \\
(0.0850)\end{array}$ \\
\hline Operating margin & $\begin{array}{l}1.000 \\
(0.000305)\end{array}$ & $\begin{array}{l}0.998 \\
(0.0445)\end{array}$ & $\begin{array}{l}1.000 \\
(0.000202)\end{array}$ & $\begin{array}{l}0.674 * * \\
(0.135)\end{array}$ & $\begin{array}{l}0.716^{* *} \\
(0.117)\end{array}$ & $\begin{array}{l}0.351 * * * \\
(0.115)\end{array}$ & $\begin{array}{l}0.392 \\
(0.359)\end{array}$ \\
\hline Total assets per employee & $\begin{array}{l}0.973 \\
(0.0715)\end{array}$ & $\begin{array}{l}0.993 \\
(0.211)\end{array}$ & $\begin{array}{l}1.303 * \\
(0.209)\end{array}$ & $\begin{array}{l}1.447 \\
(0.408)\end{array}$ & $\begin{array}{l}0.965 \\
(0.242)\end{array}$ & $\begin{array}{l}0.706 * \\
(0.132)\end{array}$ & $\begin{array}{l}1.003 \\
(0.206)\end{array}$ \\
\hline Employees & $\begin{array}{l}1.024 \\
(0.0305)\end{array}$ & $\begin{array}{l}1.113^{*} \\
(0.0717)\end{array}$ & $\begin{array}{l}1.048 \\
(0.0758)\end{array}$ & $\begin{array}{l}1.167 * * \\
(0.0915)\end{array}$ & $\begin{array}{l}1.556^{* * * *} \\
(0.176)\end{array}$ & $\begin{array}{l}1.269 * * * \\
(0.0729)\end{array}$ & $\begin{array}{l}1.077 \\
(0.148)\end{array}$ \\
\hline 5-9 years old & $\begin{array}{l}1.017 \\
(0.0857)\end{array}$ & $\begin{array}{l}1.599 * \\
(0.392)\end{array}$ & $\begin{array}{l}1.061 \\
(0.142)\end{array}$ & $\begin{array}{l}3.105^{* * *} \\
(0.996)\end{array}$ & $\begin{array}{l}1.566^{* * *} \\
(0.325)\end{array}$ & $\begin{array}{l}0.744 \\
(0.190)\end{array}$ & $\begin{array}{l}0.747 \\
(0.283)\end{array}$ \\
\hline $10-14$ years old & $\begin{array}{l}1.101 \\
(0.0970)\end{array}$ & $\begin{array}{l}2.332 * * * \\
(0.532)\end{array}$ & $\begin{array}{l}1.015 \\
(0.154)\end{array}$ & $\begin{array}{l}2.474 * * * \\
(0.687)\end{array}$ & $\begin{array}{l}1.777 * * * \\
(0.387)\end{array}$ & $\begin{array}{l}0.999 \\
(0.243)\end{array}$ & $\begin{array}{l}0.559 \\
(0.205)\end{array}$ \\
\hline At least 15 years old & $\begin{array}{l}0.659 * * * \\
(0.0503)\end{array}$ & $\begin{array}{l}1.807^{* * *} \\
(0.349)\end{array}$ & $\begin{array}{l}0.665 * * * \\
(0.0917)\end{array}$ & $\begin{array}{l}1.808 * * \\
(0.430)\end{array}$ & $\begin{array}{l}1.012 \\
(0.197)\end{array}$ & $\begin{array}{l}0.593 * * \\
(0.130)\end{array}$ & $\begin{array}{l}0.418 * * \\
(0.143)\end{array}$ \\
\hline Corporate group & $\begin{array}{l}1.130 * * \\
(0.0578)\end{array}$ & $\begin{array}{l}0.567^{* * *} \\
(0.0713)\end{array}$ & $\begin{array}{l}1.932 * * * \\
(0.203)\end{array}$ & $\begin{array}{l}0.502 * * * \\
(0.0771)\end{array}$ & $\begin{array}{l}2.051 * * * \\
(0.292)\end{array}$ & $\begin{array}{l}1.035 \\
(0.105)\end{array}$ & $\begin{array}{l}0.886 \\
(0.197)\end{array}$ \\
\hline Exporting status & $\begin{array}{l}1.750^{* * * *} \\
(0.0972)\end{array}$ & $\begin{array}{l}1.722 * * * \\
(0.218)\end{array}$ & $\begin{array}{l}1.967 * * * \\
(0.234)\end{array}$ & $\begin{array}{l}2.073 * * * \\
(0.329)\end{array}$ & $\begin{array}{l}2.319 * * * \\
(0.412)\end{array}$ & $\begin{array}{l}1.947 * * * \\
(0.232)\end{array}$ & $\begin{array}{l}0.957 \\
(0.220)\end{array}$ \\
\hline Internal human capital & $\begin{array}{l}1.129 * * * \\
(0.0202)\end{array}$ & $\begin{array}{l}1.220^{* * *} \\
(0.0523)\end{array}$ & $\begin{array}{l}1.282 * * * \\
(0.0490)\end{array}$ & $\begin{array}{l}1.273^{* * * *} \\
(0.0677)\end{array}$ & $\begin{array}{l}1.219 * * * \\
(0.0597)\end{array}$ & $\begin{array}{l}0.978 \\
(0.0422)\end{array}$ & $\begin{array}{l}1.005 \\
(0.0777)\end{array}$ \\
\hline Dist. to nearest city centre & $\begin{array}{l}0.948 \\
(0.0386)\end{array}$ & $\begin{array}{l}0.980 \\
(0.111)\end{array}$ & $\begin{array}{l}0.717 * * \\
(0.107)\end{array}$ & $\begin{array}{l}1.013 \\
(0.124)\end{array}$ & $\begin{array}{l}0.495 * * * \\
(0.0990)\end{array}$ & $\begin{array}{l}0.821^{* * * *} \\
(0.0535)\end{array}$ & $\begin{array}{l}0.990 \\
(0.167)\end{array}$ \\
\hline Establishments per bank & $\begin{array}{l}1.417^{* * *} \\
(0.106)\end{array}$ & $\begin{array}{l}1.562 * * \\
(0.325)\end{array}$ & $\begin{array}{l}0.659 * \\
(0.159)\end{array}$ & $\begin{array}{l}1.762^{* * * *} \\
(0.381)\end{array}$ & $\begin{array}{l}0.875 \\
(0.222)\end{array}$ & $\begin{array}{l}1.482^{* * * *} \\
(0.178)\end{array}$ & $\begin{array}{l}1.864 * * \\
(0.542)\end{array}$ \\
\hline Wage sum per inhabitant & $\begin{array}{l}0.686^{* * * *} \\
(0.0601)\end{array}$ & $\begin{array}{l}1.007 \\
(0.196)\end{array}$ & $\begin{array}{l}0.611 * * * \\
(0.111)\end{array}$ & $\begin{array}{l}1.020 \\
(0.236)\end{array}$ & $\begin{array}{l}1.047 \\
(0.217)\end{array}$ & $\begin{array}{l}0.905 \\
(0.216)\end{array}$ & $\begin{array}{l}0.408 * \\
(0.222)\end{array}$ \\
\hline Manufacturing firms & $\begin{array}{l}1.305^{* * *} \\
(0.0759)\end{array}$ & - & $\begin{array}{l}- \\
-\end{array}$ & - & $\begin{array}{l}- \\
-\end{array}$ & $\begin{array}{l}- \\
-\end{array}$ & - \\
\hline Service firms & $\begin{array}{l}0.981 \\
(0.0675)\end{array}$ & - & $\begin{array}{l}- \\
-\end{array}$ & - & - & $\begin{array}{l}- \\
-\end{array}$ & - \\
\hline Firms located in rural areas & $\begin{array}{l}1.675^{* * *} \\
(0.120)\end{array}$ & - & - & - & - & $\begin{array}{l}- \\
-\end{array}$ & - \\
\hline Firms located in metro areas & $\begin{array}{l}1.155^{*} \\
(0.101)\end{array}$ & $\begin{array}{l}1.933 * * * \\
(0.373)\end{array}$ & $\begin{array}{l}0.492 * * * \\
(0.0873)\end{array}$ & $\begin{array}{l}- \\
-\end{array}$ & $\begin{array}{l}- \\
-\end{array}$ & $\begin{array}{l}- \\
-\end{array}$ & - \\
\hline
\end{tabular}


Table 3 continued

\begin{tabular}{|c|c|c|c|c|c|c|c|}
\hline & \multirow[t]{2}{*}{ All regions } & \multicolumn{2}{|c|}{ Urban and metro regions } & \multicolumn{2}{|c|}{ Urban regions } & \multicolumn{2}{|c|}{ Rural regions } \\
\hline & & Manuf. & Services & Manuf. & Services & Manuf. & Services \\
\hline \multirow[t]{2}{*}{ Constant } & $0.294 * *$ & $0.0430 * *$ & $18.12 *$ & $0.0236^{* *}$ & 0.200 & $0.105^{*}$ & 0.575 \\
\hline & $(0.177)$ & $(0.0636)$ & (31.08) & $(0.0395)$ & $(0.377)$ & $(0.144)$ & $(1.670)$ \\
\hline Observations & 2160 & 564 & 421 & 415 & 234 & 699 & 132 \\
\hline Pseudo- $R^{2}$ & 0.041 & 0.059 & 0.103 & 0.101 & 0.153 & 0.042 & 0.056 \\
\hline $\operatorname{LR} \chi^{2}$ & $505.48 * * *$ & $135.86^{* * *}$ & $299.55 * * *$ & $212.52 * * *$ & $282.72 * * *$ & $139.39 * * *$ & $71.49 * * *$ \\
\hline AIC & $11,950.85$ & 2215.658 & 2630.458 & 2178.701 & 1778.615 & 3665.331 & 916.514 \\
\hline Mean VIF & 2.14 & 1.94 & 2.07 & 1.75 & 1.77 & 1.82 & 1.91 \\
\hline
\end{tabular}

$* * * p<0.01 ; * * p<0.05 ; * p<0.1$. Standard errors are displayed in parentheses. All results are estimated by maximum likelihood using a logit model, with the dependent variable equal to 1 if the firm experienced difficulties obtaining external financial capital during 2008-2010 and 0 otherwise. All independent variables are from 2007. The category urban regions exclude the metro municipalities of Stockholm, Gothenburg and Malmö

both output and returns and therefore require a higher level of monitoring, the cost of which is negatively related to distance.

Being close to a financial intermediary also facilitates a long-term relationship that enables the transfer of soft information, which reduces information asymmetry. Therefore, it is of interest to observe that although we have experienced an era of digitalisation both in society as a whole and in the banking sector, physical distance still matters. This finding lends support to the studies of Boot and Marinč (2008) and Petersen and Rajan (2002), who find that banking remains dependent upon personal relationships. In this regard, it is of course important to distinguish between private customers and corporate customers, as they have different needs and request different services and support. Corporate customers generally demand larger loans, are involved in riskier projects and require more monitoring. Private customers tend to differ in these respects.

From the bank's point of view, proximity to the firm lowers the cost of monitoring and screening, which facilitates granting loans of a riskier nature. Being in the same location also gives the bank access to local knowledge about possible markets the firm will act in. An increased distance between the firm and the bank is accompanied by higher risk, implying that monitoring the firm becomes more difficult and may result in a higher interest rate. These are factors that are influenced by the geographical distance between the bank branch and the firm and could provide an underlying explanation for this study's findings.

The above results are reinforced by the finding regarding the variable that measures the number of bank branches within a radius of $5 \mathrm{~km}$ from the firm. This variable is significant and below one, indicating a negative relationship with firms' perceived difficulties in accessing external financial capital, confirming Hypothesis 2 . The closer banks are located to a firm, the less likely the firm is to experience external capital problems. Thus, it is not necessarily the distance to the closest bank that is relevant but the total supply of bank branches, a finding in accordance with Degryse and Ongena (2005) and Beck et al. (2004). Because a firm can access more bank branches in 
the local area, it is less likely to encounter difficulties obtaining external funding for innovation activities. A larger number of bank branches in the close surroundings facilitate access to financing, as it becomes easier for firms to switch banks in case of rejection or if better services (such as lower interest rates and lower rejection rates) are offered elsewhere, because of competitive pressures. The findings support studies that conclude that reduced market power and increased competitiveness are beneficial for firms (Beck et al. 2004; Berger et al. 1999; Degryse and Ongena 2005; Dinc 2000; Gilbert 1984; Sharpe 1990).

The firm's location relates to how access to banks influences perceptions of firms' access to external capital. In more rural regions, where the largest decrease in the number of bank branches has occurred, it is the distance to the closest bank branch that relates to perceptions of access to external capital. Firms that are closer to bank branches are less likely to perceive problems accessing external capital. For firms in urban locations, Sweden's major cities and the suburbs in our three metropolitan regions, it is not distance per se but the number of local bank branches that is associated with firms' perceptions of difficulties accessing capital. More bank branches in a firm's vicinity are positively associated with the ability to acquire external capital.

Comparing different regions and sectors, perceptions of problems in accessing external capital for service firms are to a larger extent related to distance to the closest bank, whereas the same relationship is observed for manufacturing firms for the number of bank branches in the vicinity. One possible explanation for this difference lies in the structure of firms. In general, service firms have less fixed capital and collateral than manufacturing firms. Accordingly, service firms are disadvantaged when applying for loans and must rely more on soft information that is built up through relationships, which are distance sensitive.

The discussion up to this point has been based on the average effects of the variables of interest. To illustrate how these effects, change for different values, Fig. 2 shows the fitted values of the probability of perceiving difficulties in acquiring financial capital with respect to distance to the nearest bank and the number of bank branches in the near surroundings. This effect is divided according to regional and industry classification.

The clear differences between manufacturing and service firms are visible in the figures. In relation to the number of bank branches that are accessible in close surroundings, we observe a sharp decrease in the fitted values for manufacturing firms. For service firms, the decline is less pronounced. For distance to the nearest bank, we see a clear pattern for service firms, whereas for manufacturing firms, we observe conflicting patterns for urban and rural manufacturing firms. For service firms, regardless of whether they are in urban or rural areas, firms characterised by longer distances to the nearest bank branch are more likely to report problems acquiring external capital than firms characterised by shorter distances to the nearest bank branch.

The size of these effects can also be quantified through predicted values. A manufacturing firm located in an urban area with no banks within $5 \mathrm{~km}$, all else equal, has a probability of approximately 0.7 to experience problems when acquiring external capital. When the same firm has one bank the probability drops to 0.59 and for three banks it drops to 0.48 . The same exercise for an average rural firm yields the figures 0.53 for no banks, 0.48 for one bank and 0.42 for three banks, all else equal. It thus appears that the average manufacturing firm is worse off with no banks in the vicinity in an 


\section{Manufacturing firms}
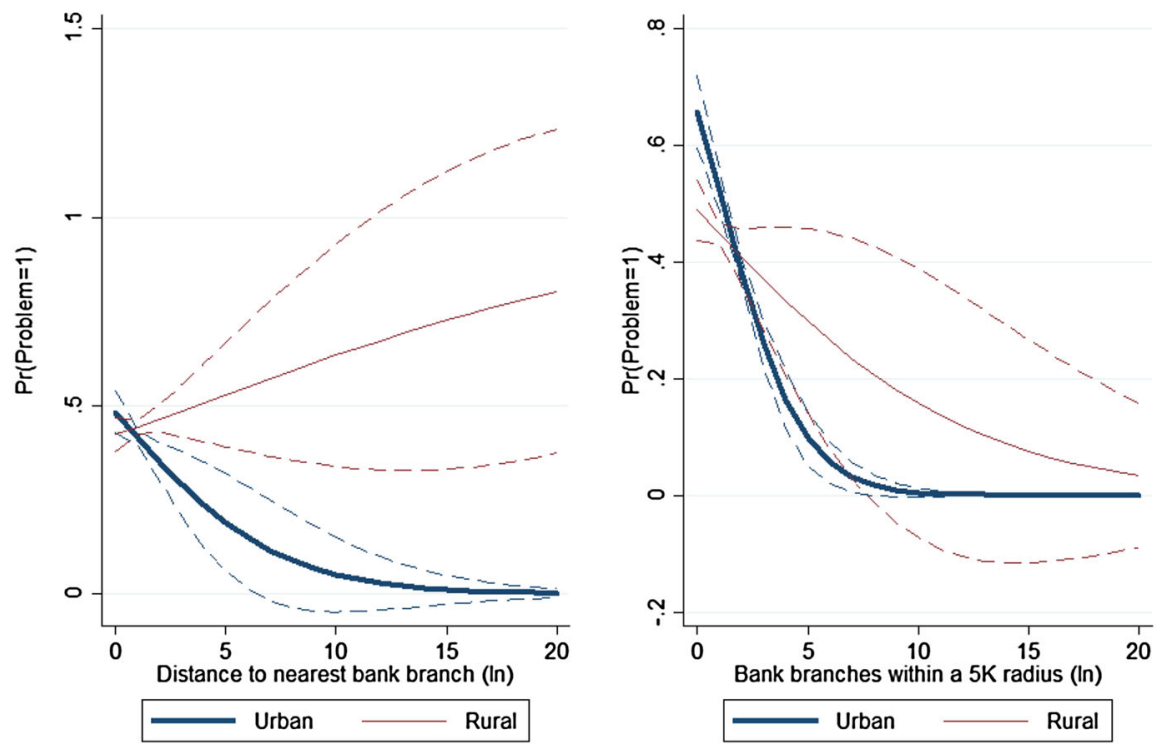

\section{Service firms}
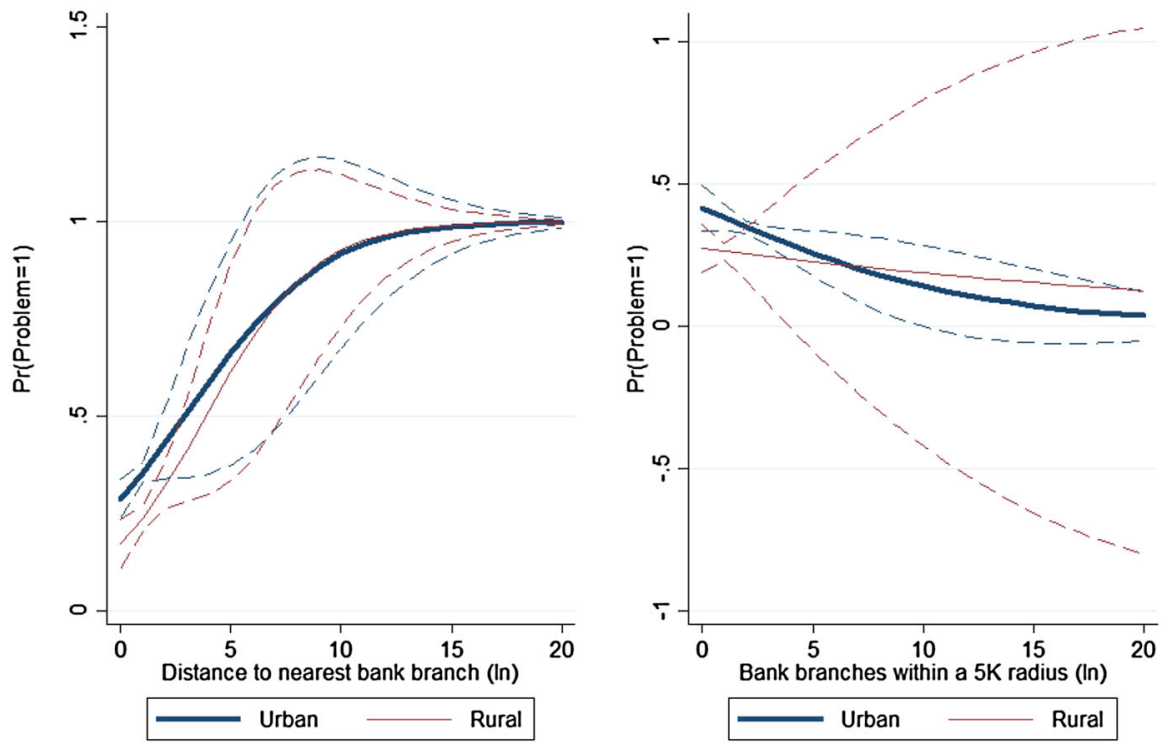

Fig. 2 Fitted values of the dependent variable (solid lines), with 95\% confidence intervals (dashed lines) 
urban area than in a rural area. However, as the number of banks increases, the firms eventually, after eight bank branches, have the same probability of experiencing problems with the acquisition of external capital. However, one should bear in mind that there are more bank branches available in urban areas and a firm located there is more likely to end up in a situation with, e.g. eight bank branches within a $5 \mathrm{~km}$ radius, than a firm located in a rural area.

The results for service firms indicated that the distance to the nearest bank branch was more important than the number of bank branches in the vicinity. Thus, a similar exercise with the probability to experience external capital problems with varying Euclidean distances is interesting for the service sector. For the average service firm in an urban area, the probability of experiencing problems when having a bank branch in the same location (i.e. a distance of $0 \mathrm{~km}$ ) is 0.31 , all else equal. As the distance increases to $5 \mathrm{~km}$ the probability has increased to 0.59 and for 10 and $20 \mathrm{~km}$ the probability is 0.68 and 0.76 , respectively. The average service firm in a rural area have a probability of 0.16 if the bank is located at the same location. As the distance increases to 5,10 and $20 \mathrm{~km}$, the probability increases to $0.33,0.41$ and 0.49 all else equal.

These predicted values indicate that the average firm in an urban area is more likely to experience problems than the average firm in an urban area, potentially due to a higher level of competition, which was also suggested by Petersen and Rajan (1995). However, one should also be aware that the financial supply in general is smaller in rural areas, and consequently, firms located there are more likely to have fewer banks within a short distance than a firm in an urban area.

\subsubsection{Control variables}

A shorter distance between firms and state-financed capital (Almi) increases the probability of reporting external financing problems. This could be related to a higher competition for capital seen in the regional centres, where these offices are located. With respect to firms' financial information, the odds ratio for the operating margin indicates a negative relationship with the probability of experiencing external capital problems, confirming previous studies (Berger and Udell 2006; Mina et al. 2013; Uchida 2011). Conversely, total assets per employee are generally not related to external capital problems.

One surprising result is that the number of employees is positively associated with firms' perceptions of difficulties in accessing external capital. Studies normally highlight small firms as those that are disadvantaged (Becchetti and Trovato 2002; Företagarna 2015; Pollard 2003). However, it is important to bear in mind that the CIS sample excludes micro-firms; therefore, variations in the number of employees begin at a threshold of ten employees and we cannot observe any potential problems for those firms. However, the results show that rather small firms are not disadvantaged vis-à-vis large ones, all else equal. Why this is the case would be an interesting question for further studies.

The relationship between age and firm perceptions tends to follow an inverted Ushape. Semi-old firms (10-14 years since establishment) experience greater difficulties attracting external capital than newly established firms. Old firms (at least 15 years 
since establishment) experience fewer problems acquiring external capital. That old firms have fewer problems could be attributable to a greater availability of financial records and more experience within the sector and is in line with previous studies, such as Mina et al. (2013) and Balasubramanian and Lee (2008), while the younger firms are more likely to receive support from various business developing agencies.

Exporting status is consistently positively related to external capital problems, suggesting that investors do not regard trade involvement as a positive sign of productivity. One possible reason for this is offered by Mina et al. (2013), who suggest that involvement in international markets could lead to decreased transparency regarding firm operations and increased agency problems, thus discouraging investment. Internal human capital is positively related to external capital problems, suggesting that more highly educated employees increase the probability of experiencing financing difficulties, which may seem counterintuitive. However, the same result was found by Mina et al. (2013) for the USA. They suggest that this result may reflect high-tech firms, which employ more highly skilled workers and have greater information asymmetry vis-à-vis investors. The final firm-specific variable is distance to the nearest city centre, where the odds ratio is either not significantly different from one or it is significantly lower-suggesting no or a negative relationship. Because rents are higher in the city centre than in the periphery, firms may be more likely to have sound finances (and therefore, a better financial record to show investors) if they are not located in the city centre. There is also a possibility that the competition decreases further away from the central business district.

The odds ratio for the first region-specific variable suggest that firms located in areas where the ratio of establishments per bank branch is high have greater difficulties acquiring external capital, most likely because of stronger competition for the region's financial supply. The odds ratio for the second regional-specific variable, regional wealth, indicates that firms located in wealthier regions are less likely to experience external capital problems. This finding could be attributable to a larger regional supply of financial capital, depending on the internal structure of the banks.

\subsubsection{Sensitivity analysis}

As mentioned in Table 3, the metropolitan municipalities were excluded due to extreme values of financial capital supply.

To test the robustness of our results, we perform several sensitivity analyses, presented in Table 4. To assess whether the cumulative distribution function of the error term, which is logistically distributed in a logit model and normally distributed in a probit model, affects the results, we have also conducted a probit estimation, with similar results. One factor that is not considered in our model is previous innovative behaviour, which could be relevant, as firms in the CIS survey reported whether financial constraints have hindered their innovation processes. In addition, many studies have concluded that firms that have innovated previously learn from those processes and use their accumulated knowledge to generate future innovations (Geroski et al. 1997; Malerba et al. 1997; Roper and Hewitt-Dundas 2008). The problem with the CIS data is that all questions are asked during the same period, but we wish to know about their past behaviour. To remedy this problem, we add information from the pre- 
Table 4 Regression results for the main variables, using alternative specifications, are displayed as odds ratios

\begin{tabular}{|c|c|c|c|c|c|}
\hline \multirow[t]{2}{*}{ Alternative specification } & \multirow[t]{2}{*}{ Variables } & \multicolumn{2}{|c|}{ Urban regions } & \multicolumn{2}{|c|}{ Rural regions } \\
\hline & & Manuf. & Services & Manuf. & Services \\
\hline \multirow[t]{4}{*}{$\begin{array}{l}\text { Controlling the previous innovation } \\
\text { status in CIS } 2008\end{array}$} & Dist. to nearest bank branch & $\begin{array}{l}0.485^{* * *} \\
(0.0769)\end{array}$ & $\begin{array}{l}2.349 * * * \\
(0.722)\end{array}$ & $\begin{array}{l}1.291 * * * \\
(0.123)\end{array}$ & $\begin{array}{l}15.23 * * * \\
(8.306)\end{array}$ \\
\hline & Bank branches within $5 \mathrm{~km}$ & $\begin{array}{l}0.421^{* * *} \\
(0.0487)\end{array}$ & $\begin{array}{l}0.588 * * * \\
(0.0810)\end{array}$ & $\begin{array}{l}0.954 \\
(0.125)\end{array}$ & $\begin{array}{l}1.307 \\
(0.475)\end{array}$ \\
\hline & Observations & 401 & 161 & 563 & 74 \\
\hline & Pseudo- $R^{2}$ & 0.128 & 0.268 & 0.058 & 0.228 \\
\hline \multirow[t]{4}{*}{$\begin{array}{l}\text { Including firms whose nearest bank } \\
\text { relocated during 2008-2010 }\end{array}$} & Dist. to nearest bank branch & $\begin{array}{l}0.730 * * \\
(0.0893)\end{array}$ & $\begin{array}{l}1.484 * * \\
(0.295)\end{array}$ & $\begin{array}{l}1.094 \\
(0.0836)\end{array}$ & $\begin{array}{l}1.538 * * \\
(0.260)\end{array}$ \\
\hline & Bank branches within $5 \mathrm{~km}$ & $\begin{array}{l}0.529 * * * \\
(0.0480)\end{array}$ & $\begin{array}{l}0.836^{*} \\
(0.0786)\end{array}$ & $\begin{array}{l}0.844^{*} \\
(0.0861)\end{array}$ & $\begin{array}{l}0.949 \\
(0.229)\end{array}$ \\
\hline & Observations & 575 & 298 & 808 & 150 \\
\hline & Pseudo- $R^{2}$ & 0.091 & 0.139 & 0.037 & 0.075 \\
\hline \multirow{4}{*}{$\begin{array}{l}\text { Transforming the variables Dist. to } \\
\text { nearest bank branch and Bank } \\
\text { branches within } 5 \mathrm{~km} \text { to changes } \\
\text { over the period } 2003-2007\end{array}$} & $\begin{array}{l}\text { Change in dist. to nearest } \\
\text { bank branch }\end{array}$ & $\begin{array}{l}0.961 \\
(0.0670)\end{array}$ & $\begin{array}{l}1.491 * \\
(0.323)\end{array}$ & $\begin{array}{l}1.012 \\
(0.0200)\end{array}$ & $\begin{array}{l}1.261 * * * \\
(0.0808)\end{array}$ \\
\hline & $\begin{array}{l}\text { Change in bank branches } \\
\text { within } 5 \mathrm{~km}\end{array}$ & $\begin{array}{l}0.955 \\
(0.0367)\end{array}$ & $\begin{array}{l}1.144 * * * \\
(0.0352)\end{array}$ & $\begin{array}{l}1.029 \\
(0.0746)\end{array}$ & $\begin{array}{l}3.497 * * * \\
(0.578)\end{array}$ \\
\hline & Observations & 575 & 298 & 808 & 150 \\
\hline & Pseudo- $R^{2}$ & 0.069 & 0.144 & 0.035 & 0.150 \\
\hline
\end{tabular}

$* * * p<0.01 ; * * p<0.05 ; * p<0.1$. Standard errors are displayed in parentheses. All results are estimated by maximum likelihood using a logit model, where the dependent variable is 1 if the firm experienced problems obtaining external financial capital during 2008-2010 and 0 otherwise. Data for all independent variables are from 2007 and can be obtained upon request. The category "urban" excludes the municipalities of Stockholm, Gothenburg and Malmö

vious CIS survey, covering the 2006-2008 period. The disadvantage of adding this information, and the reason we opted not to use these data in our main analysis, is that we lose $30-50 \%$ of the sample. Nevertheless, we add the information as a robustness check, and in most cases, the results regarding access to banks correspond to the findings presented in Table 3 . We observe that proximity decreases the probability that a firm will report a problem in acquiring external capital. One exception, however, is manufacturing firms in urban municipalities. As also found above, we observe that a larger number of bank branches within a radius of $5 \mathrm{~km}$ are negatively associated with firm perceptions of problems accessing external capital. In this case, however, this is only true for urban municipalities.

In a second sensitivity test, we include only firms whose nearest bank relocated during 2008-2010. The results confirm previous findings regarding overall access to banks. Compared to the results reported in Table 3, we observe that for manufacturing firms, distance to the nearest bank branch is not positively related to firm perceptions.

Instead of using only the static variables of distance and number of bank branches, we also analyse changes in the variables. We have transformed distance to the nearest 
bank branch and the number of bank branches within $5 \mathrm{~km}$ to capture changes over the period 2003-2007. The variable is calculated as the distance/number of banks in 2003 minus the value from 2007. Thus, a positive value for change in distance means that distance to the nearest bank has decreased. It is therefore surprising to observe a significant odds ratio above one, as this indicates that firms that have experienced a decrease in distance are more likely to perceive difficulties in accessing external capital. One potential reason for this finding is that almost $86 \%$ of rural firms have not experienced changes, and the equivalent value for urban firms is $73 \%$. Thus, most firms have not experienced any changes, and the coefficients are therefore driven by a few cases. For the change in the number of bank branches within a radius of $5 \mathrm{~km}$, a lower value indicates that firms had more bank branches within their vicinities in 2007 than in 2003. A significant odds ratio above one suggests that a greater number of bank branches lead firms to perceive that they have greater access to external capital, which is in line with expectations.

Another problem is endogeneity; because the data are cross-sectional, reverse causality is particularly pertinent. To address this issue, we use independent variables from 2007, the year before the 2008-2010 period covered by the survey and 4 years before 2011, when the firms responded to the survey. We also include a wide range of firm characteristics to reduce the problem of unobserved firm heterogeneity in the dataset. One such example is information about firms' previous innovation activities, which is controlled in the sensitivity analysis displayed in Table 4. The results are similar to the main results displayed in Table 3. Another such example is the variables depicting the firms' financial situation that is intended to reduce the issue of creditworthiness being unobserved. It could also be the case that firms that are less creditworthy are not able to locate in cities, or near those offices in cities due to higher rents. To reduce this issue, we split the sample for firms located in urban and rural areas to ensure that they are not compared directly. The Euclidean distance to the nearest city centre within the region is also added as a control variable.

A selection bias may also be present due to potential differences in behaviour between movers and stayers in regions. On average, $7 \%$ of the firms in the dataset moved annually, so this does not comprise a large part of the firms. In general, manufacturing firms were less likely to move, which is logical since they often have much physical capital that is not convenient to move. To explore that issue further, we ran separate regressions for samples with only movers and only stayers. These results indicated that movers were not so sensitive to the distance to their nearest bank, but the odds ratios still suggest that a higher number of bank branches within $5 \mathrm{~km}$ are associated with experiencing fewer difficulties to obtain external financial capital. The results for the stayers are in line with the main results in Table 3; manufacturing firms are more sensitive to the number of bank branches in their vicinity, while the service firms are more sensitive to the Euclidean distance to the closest branch. These results could suggest that at least service firms that are more mobile due to the nature of their operations to some extent do relocate to improve their situation as the external environment changes. 


\section{Conclusions}

Sweden, like many other developed countries, has recently experienced a change in its local financial infrastructure. For example, half of the existing bank branches closed between 1993 and 2010. The largest change can be observed in rural areas, which, before the bank closures, had few financial resources other than traditional bank loans. The purpose of this study is to analyse the potential consequences of this development in the banking sector by examining whether low access to banks, in terms of longer Euclidean distance to the nearest bank branch (Hypothesis 1) and fewer bank branches within a radius of $5 \mathrm{~km}$ (Hypothesis 2), is related to greater difficulties for firms in accessing external capital for innovation activities.

The study used a question from the 2010 wave of the CIS about problems experienced obtaining external capital. This question was combined with detailed geo-coded firm-level data, enabling us to calculate the Euclidean distance to the nearest bank branch and the total number of bank branches within a radius of $5 \mathrm{~km}$ of each firm. Our hypothesis that closer geographical proximity is negatively related to the probability that a firm experiences difficulty obtaining external capital was confirmed, as was the hypothesis that a larger number of bank branches within the vicinity of a firm are negatively related to the probability that the firm will experience external capital problems. These findings highlight the importance of a local bank presence, even in the era of digitalisation. Thus, the importance of geography in finance still prevails as similar innovative firms in different locations will face different obstacles in obtaining finance. By observing the continuation of bank branch closures in Sweden, up to 2015, we can conclude that the trend displayed in Fig. 1 has been cemented and enforced. From 2010 to 2015, the number of bank branches has increased only in the metropolitan municipalities while all other regional categories have experience a contraction of the regional supply of banks. This is especially prevalent in sparsely populated rural locations where $17 \%$ of all bank branches closed down during this period, implying that 86 bank branches supply approximately half of the Swedish area. The high rate of bank branch closure, especially in rural areas, could have long-term consequences for firms' competitiveness and in turn for local and regional economic development.

The closure of bank branches has received attention from media and policy makers. The nature of the underlying problem is, however, hard to know. If the bank branches are closed down due to lack of profitable projects in these areas, banks are acting in accordance with changes in the market and there is no underlying market failure. Given the findings in this paper and by other studies, the local presence of banks is, however, of importance for the regional well-being, and once all bank branches have closed down, it can reinforce the negative trend observed especially in the rural areas. Thus, it gives clear incentives to policy makers to monitor the development of bank branches and have an overarching strategy that combines all the different alternative financial instruments and coordinate them appropriately as this is missing today.

Importantly, this study is of a cross-sectional nature; therefore, it is difficult to make any causal claims about the effects of bank relocations, which are common in Sweden and shared with many other developed countries. If more waves of the CIS that include the question about hindrances to innovation activities used in this study as a dependent variable were available, a longitudinal study that follows these firms over time could 
be conducted. Another intriguing way of examining the issue, if data availability were to permit, would be to utilise actual firm-level investment information, similar to Mina et al. (2013).

Open Access This article is distributed under the terms of the Creative Commons Attribution 4.0 International License (http://creativecommons.org/licenses/by/4.0/), which permits unrestricted use, distribution, and reproduction in any medium, provided you give appropriate credit to the original author(s) and the source, provide a link to the Creative Commons license, and indicate if changes were made.

\section{References}

Agarwal S, Hauswald R (2010) Distance and private information in lending. Rev Financ Stud 23(7):2757-2788

Aghion P, Howitt P (1992) A model of growth through creative destruction. Econometrica 60:323

Alessandria G, Choi H (2007) Do sunk costs of exporting matter for net export dynamics? Q J Econ 122:289-336

Alessandrini P, Presbitero AF, Zazzaro A (2010) Bank size or distance: what hampers innovation adoption by SMEs? J Econ Geogr 10:845-881

Almi (2016) Om Almi. SNS, Stockholm (in Swedish)

Avdeitchikova S (2008) On the structure of the informal venture capital market in Sweden: developing investment roles. Venture Cap 10:55-85

Backman M (2015) Banks and new firm formation. J Small Bus Enterp Dev 22:734-761

Balasubramanian N, Lee J (2008) Firm age and innovation. Ind Corp Change 17:1019-1047

Baldwin R, Krugman P (1989) Persistent trade effects of large exchange rate shocks. Q J Econ 104:635-654

Bankföreningen S (2010) Banker i Sverige: Faktablad om svensk bankmarknad. Svenska Bankföreningen, Stockholm (in Swedish)

Becchetti L, Trovato G (2002) The determinants of growth for small and medium sized firms. The role of the availability of external finance. Small Bus Econ 19:291-306

Beck T, Levine R, Loayza N (2000) Finance and the sources of growth. J Financ Econ 58:261-300

Beck T, Demirguc-Kunt A, Maksimovic V (2004) Bank competition and access to finance: international evidence. J Money Credit Bank 36:627-648

Berger AN, Udell GF (2006) A more complete conceptual framework for SME finance. J Bank Finance 30:2945-2966

Berger AN, Demsetz RS, Strahan PE (1999) The consolidation of the financial services industry: causes, consequences, and implications for the future. J Bank Finance 23:135-194

Berggren B, Silver L (2010) Financing entrepreneurship in different regions: the failure to decentralise financing to regional centres in Sweden. J Small Bus Enterp Dev 17:230-246

Berggren B, Lindström G, Olofsson C (2001) Tillväxt och finansiering i mindre företag. In: Davidsson P, Delmar F, Wiklund J (eds) Tillväxtföretagen i Sverige. SNS Förlag, Stockholm (in Swedish)

Bernard AB, Jensen JB (2004) Why some firms export. Rev Econ Stat 86:561-569

Bernard AB, Wagner J (2001) Export entry and exit by German firms. Weltwirtschaftliches Arch 137:105-123

Blanchard P, Huiban J-P, Musolesi A, Sevestre P (2013) Where there is a will, there is a way? Assessing the impact of obstacles to innovation. Ind Corp Change 22:679-710

Boot AWA (2000) Relationship banking: what do we know? J Financ Intermed 9:7-25

Boot AWA, Marinč M (2008) The evolving landscape of banking. Ind Corp Change 17:1173-1203

Brant R (1990) Assessing proportionality in the proportional odds model for ordinal logistic regression. Biometrics 46:1171-1178

Cameron AC, Trivedi PK (2010) Microeconometrics using stata. Stata Press, College Station

Canepa A, Stoneman P (2008) Financial constraints to innovation in the UK: evidence from CIS2 and CIS3. Oxf Econ Pap 60:711-730

Cohen WM, Klepper S (1996) Firm size and the nature of innovation within industries: the case of process and product R\&D. Rev Econ Stat 78:232-243

Cole RA (1998) The importance of relationships to the availability of credit. J Bank Finance 22:959-977 
Cole RA, Goldberg LG, White LJ (2004) Cookie cutter vs. character: the micro structure of small business lending by large and small banks. J Financ Quant Anal 39:227-251

Collender RN, Shaffer S (2003) Local bank office ownership, deposit control, market structure, and economic growth. J Bank Finance 27:27-57

Cook GAS, Pandit NR, Lööf H, Johansson B (2013) Clustering, MNEs, and innovation: who benefits and how? Int J Econ Bus 20:203-227

Dachs B, Ebersberger B, Lööf H (2008) The innovative performance of foreign-owned enterprises in small open economies. J Technol Transf 33:393-406

Das S, Roberts MJ, Tybout JR (2007) Market entry costs, producer heterogeneity, and export dynamics. Econometrica 75:837-873

Degryse H, Ongena S (2005) Distance, lending relationships, and competition. J Finance 60:231-266

Degryse H, Matthews K, Zhao T (2015) SMEs and access to bank credit: evidence on the regional propagation of the financial crisis in the UK. Available at SSRN: https://ssrn.com/abstract=2655561 or http:// dx.doi.org/10.2139/ssrn.2655561

Dinc IS (2000) Bank reputation, bank commitment, and the effects of competition in credit markets. Rev Financ Stud 13:781-812

Elsas R, Krahnen JP (1998) Is relationship lending special? Evidence from credit-file data in Germany. J Bank Finance 22:1283-1316

European Commission E (2011) SMEs' access to finance, Survey 2011. European Commission and European Central Bank

Ferri G, Messori M (2000) Bank-firm relationships and allocative efficiency in Northeastern and Central Italy and in the South. J Bank Finance 24:1067-1095)

Flögel F (2017) Distance and modern banks' lending to SMEs: ethnographic insights from a comparison of regional and large banks in Germany. J Econ Geogr. Forthcoming

Företagarna (2015) Småföretagen vill växa-men saknar finansiering. Företagarna, Stockholm (in Swedish)

Fritsch M, Schilder D (2008) Does venture capital investment really require spatial proximity? An empirical investigation. Environ Plan A 40:2114-2131

Gereffi G, Humphrey J, Sturgeon T (2005) The governance of global value chains. Rev Int Polit Econ 12:78-104

Geroski PA, van Reenen J, Walters CF (1997) How persistently do firms innovate? Res Policy 26:33-48

Gilbert RA (1984) Bank market structure and competition: a survey. J Money Credit Bank 16:617-645

Goldsmith R (1969) Financial structure and development. Yale University Press, New Haven

Greene WH (2008) Econometric analysis. Pearson Prentice Hall, Upper Saddle River

Hall B (2002) The financing of research and development. Oxf Rev Econ Policy 18:35-51

Hall B, Moncada-Paternò-castello P, Montresor S, Vezzani A (2016) Financing constraints, R\&D investments and innovative performances: new empirical evidence at the firm level for Europe. Econ Innov New Technol 25:183-196

Hayek FA (1945) The use of knowledge in society. Am Econ Rev 35:519-530

Hubbard RG (1998) Capital-market imperfections and investment. J Econ Lit 36:193-225

Johansson B, Lööf H (2008) Innovation activities explained by firm attributes and location. Econ Innov New Technol 17:533-552

King RG, Levine R (1993) Finance and growth: Schumpeter might be right. Q J Econ 108:717-737

Kwast ML (1999) Bank mergers: what should policymakers do? J Bank Finance 23:629-636

Lee N, Brown R (2017) Innovation, SMEs and the liability of distance: the demand and supply of bank funding in UK peripheral regions. J Econ Geogr 17(1):233-260

Lööf H, Nabavi P (2016) Innovation and credit constraints: evidence from Swedish exporting firms. Econ Innov New Technol 25:269-282

Lundvall B-Å (ed) (1992) National systems of innovation-towards a theory of innovation and interactive learning. Pinter, London

Lutz E, Bender M, Achleitner A-K, Kaserer C (2013) Importance of spatial proximity between venture capital investors and investees in Germany. J Bus Res 66:2346-2354

Majocchi A, Bacchiocchi E, Mayrhofer U (2005) Firm size, business experience and export intensity in SMEs: a longitudinal approach to complex relationships. Int Bus Rev 14:719-738

Malerba F, Orsenigo L, Peretto P (1997) Persistence of innovative activities, sectoral patterns of innovation and international technological specialization. Int J Ind Organ 15:801-826

Månsson N, Landström H (2006) Business angels in a changing economy: the case of Sweden. Venture Cap 8:281-301 
Mina A, Lahr H, Hughes A (2013) The demand and supply of external finance for innovative firms. Ind Corp Change 22:869-901

Mohnen P, Palm FC, van der Loeff SS, Tiwari A (2008) Financial constraints and other obstacles: are they a threat to innovation activity? De Econ 156:201-214

Nelson RR, Winter SG (1982) An evolutionary theory of economic change. The Belknap Press of Harvard University Press, Cambridge

O'sullivan M (2005) Finance and innovation. In: Fagerberg J, Mowery DC, Nelson RR (eds) The Oxford handbook of innovation. Oxford University Press, Oxford

Papi L, Sarno E, Zazzaro A (2015) The geographical network of bank organizations: issues and evidence for Italy. In: Martin R, Pollard J (eds) Handbook of geographies of money and finance. E. Elgar Publisher, Cheltenam

Petersen MA, Rajan RG (1995) The effect of credit market competition on lending relationships. Q J Econ 110:407-443

Petersen MA, Rajan RG (2002) Does distance still matter? The information revolution in small business lending. J Finance 57:2533-2570

Pfeffermann D (1993) The role of sampling weights when modeling survey data. Int Stat Rev 61:317-337

Pollard JS (2003) Small firm finance and economic geography. J Econ Geogr 3:429-452

Reynolds P, Bygrave W, Autio E (2003) Global Entrepreneurship Monitor 2003 Executive Report. Global Entrepreneurship Monitor. Babson College, Wellesly

Roper S, Hewitt-Dundas N (2008) Innovation persistence: survey and case-study evidence. Res Policy 37:149-162

Scherer FM (1965) Size of firm, oligopoly, and research: a comment. Can J Econ Polit Sci 31:256-266

Schumpeter J (1911) The theory of economic development. Transaction Publishers, Piscataway

Schumpeter J (1934) The theory of economic development: an inquiry into profits, capital, credit, interest, and the business cycle. Harvard University Press, Cambridge

Schumpeter J (1939) Business cycles. McGraw Hill, New York

Sharpe SA (1990) Asymmetric information, bank lending and implicit contracts: a stylized model of customer relationships. J Finance 45:1069-1087

Sjögren H, Zackrisson M (2005) The search for competent capital: financing of high technology small firms in Sweden and USA. Venture Cap 7:75-97

Söderblom A (2012) The current state of the venture capital industry. In: Näringspolitiskt forum. Entreprenörskapsforum, Örebro

Söderblom A, Samuelsson M (2014) Sources of capital for innovative startup firms. In: Näringspolitiskt forum. Entreprenörskapsforum, Örebro

Statistics Sweden (2012) Innovation activity in Swedish enterprises 2008-2010. Statistics Sweden

Stein JC (2002) Information production and capital allocation: decentralized versus hierarchical firms. J Finance 57(5):1891-1921

Stenfors A (2014) The Swedish financial system. In: School LUB (ed) Studies in financial systems. FESSUD, Leeds

Storper M, Venables AJ (2004) Buzz: face-to-face contact and the urban economy. J Econ Geogr 4:351-370

Thornhill S (2006) Knowledge, innovation and firm performance in high- and low-technology regimes. J Bus Ventur 21:687-703

Uchida H (2011) What do banks evaluate when they screen borrowers? Soft information, hard information and collateral. J Financ Serv Res 40:29-48

Udell GF (2008) What's in a relationship? The case of commercial lending. Bus Horiz 51:93-103

Westlund H (2011) Multidimensional entrepreneurship: theoretical considerations and Swedish empirics. Reg Sci Policy Pract 3:199-218

Zhao T, Jones-Evans D (2017) SMEs, banks and the spatial differentiation of access to finance. J Econ Geogr 17(4):791-824 